Agnieszka Fluda-Krokos Uniwersytet Pedagogiczny w Krakowie Instytut Nauk o Informacji

\title{
Problematyka kształcenia akademickiego pracowników bibliotek i informacji naukowej na łamach czasopism specjalistycznych (1945-2015)
}

C C istoria akademickiego kształcenia bibliotekarzy w Polsce sięga kowski w Gimnazjum Wołyńskim w Krzemieńcu (1809-1831), Jerzy Samuel Bandtkie w Uniwersytecie Jagiellońskim (1811-1834), Joachim Lelewel w Uniwersytecie Warszawskim (1821) i Aleksander Bohatkiewicz w Uniwersytecie Wileńskim (1829-1831). W Szkole Głównej Warszawskiej w latach 1865-1868 kierownikiem katedry bibliografii był Karol Estreicher. W pierwszej połowie wieku XX Stefan Vrtel-Wierczyński prowadził wykłady z bibliografii i bibliotekoznawstwa w Uniwersytecie im. Jana Kazimierza we Lwowie (1924-1928) i księgoznawstwa w Uniwersytecie Poznańskim (1936), a Aleksander Birkenmajer wykład ze wstępu do bibliotekoznawstwa w Uniwersytecie Jagiellońskim (1938). Jednak w pełni zinstytucjonalizowane jako akademickie bibliotekoznawstwo datuje się od roku 1945 - powstanie Katedry Bibliotekoznawstwa w Uniwersytecie Łódzkim. Kolejne samodzielne jednostki powołane zostały w Warszawie (1952) oraz Wrocławiu (1956) ${ }^{1}$.

${ }^{1}$ B. Sosińska-Kalata: Koncepcja nauczania bibliotekarzy i pracowników informacji naukowej w Polsce po II wojnie światowej. W: Bibliotekoznawstwo i informacja naukowa. Kształcenie w perspektywie nowego stulecia. Red. E.B. Zybert. Warszawa 1995, s. 30-51; Z. Gębołyś: Zawód bibliotekarza i ksztatcenie bibliotekarzy w Polsce. W: Bibliotekarstwo. Red. Z. Żmigrodzki. Warszawa 1998, s. 382-402; J. Puchalski: Organizacja kształcenia bibliotekarzy i pracowników informacji naukowej w Polsce w okresie międzywojennym. W: Bibliotekoznawstwo i informacja naukowa..., s. 12-18; J. Wojakowski: Organizacja ksztatcenia bibliotekarzy i pracowników informacji naukowej w Polsce po zakończeniu drugiej wojny światowej. W: ibidem, s. 19-29; H. Więckowska: Akademickie kształcenie bibliotekarzy: zarys historyczny. Warszawa 1979. 
Kształceniu bibliotekarskiemu poświęcono wiele dyskusji, konferencji i publikacji². Areną relacji, wymiany poglądów, przedstawiania założeń i realizacji programów kształcenia były i są czasopisma branżowe. Niniejszy tekst ma na celu przedstawienie zarysu problematyki kształcenia

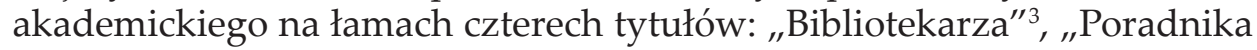
Bibliotekarza"4, „Przeglądu Bibliotecznego" ${ }^{5}$ oraz "Zagadnień Informacji Naukowej" ${ }^{6}$. Zaznaczyć należy również, że przeanalizowany materiał dotyczy jedynie edukacji na poziomie akademickim w Polsce, ze szczególnym zwróceniem uwagi na teksty polemiczne i poruszające zagadnienia programów i form studiów oraz zmian w nich zachodzących. Na łamach wymienionych czasopism często pojawiała się także tematyka kształcenia na poziomie średnim, kursów czy awansów zawodowych bibliotekarzy, tematy te jednak wymagają oddzielnego opracowania.

W badaniu posłużono się metodami analizy ilościowej i treściowej, wyodrębniając z wymienionych tytułów czasopism ok. 200 artykułów poświęconych kształceniu akademickiemu bibliotekarzy na przestrzeni niemalże 70 lat $^{7}$.

${ }^{2}$ Są to m.in. Bibliotekarz uwolniony - deregulacja czy degradacja?: IV Ogólnopolska Konferencja Naukowa Białystok, 12-14 czerwca 2013 r. Red. H. Brzezińska-Stec, J. Żochowska. Białystok 2013; Kształcenie bibliotekarzy na potrzeby środowisk lokalnych. Programy ksztatcenia uniwersyteckiego. Tom I-II. Red. E. Chuchro, M. Ochmański, M. Zając. Warszawa 2011; Aktualizacja ksztatcenia akademickiego bibliotekarzy pracujacych w matych bibliotekach gminnych. Red. E. Chuchro, M. Ochmański, M. Zając. Warszawa 2010; M. Kocójowa: Ocena jakości studiów bibliotekoznawstwa i informacji naukowo-technicznej [dalej BIN] w Polsce i akredytacja. W: Społeczeństwo informacyjne: jakość edukacji i pracy bibliotekarzy. Red. nauk. M. Kocójowa. Kraków 2001, s. 36-47; Światowa strategia edukacji bibliotekarzy i specjalistów informacji naukowej. Red. nauk. M. Kocójowa. Kraków 1998; Edukacja bibliotekarzy 2001: materiaty z konferencji międzynarodowej, Warszawa, 6-7 października 1998 r. Warszawa 1998; Edukacja z zakresu bibliotekoznawstwa i informacji naukowej na poziomie wyższym w Polsce. Status i przyszłość: Ogólnopolska Konferencja w Krakowie, 26 kwietnia 1995 r. Red. M. Kocójowa. Kraków 1995; Kształcenie bibliotekarzy szkolnych. Red. J. Jarowiecki. Kraków 1993; Bibliotekarze, zawód, osobowość, kwalifikacje. Red. K. Dąbrowska. Warszawa 1990; Z. Gaca-Dąbrowska: Akademickie kształcenie bibliotekarzy dla potrzeb bibliotek publicznych, zwiazkowych i szkolnych. Poznań 1980; S. Kubiak: Ksztatcenie bibliotekarzy i pracowników informacji naukowej na poziomie wyższych w Polsce. Zielona Góra 1975.

3 "Bibliotekarz" - czasopismo bibliotekarskie, ukazujące się z przerwami od roku 1909.

4 "Poradnik Bibliotekarza" - czasopismo bibliotekarskie, ukazujące się z przerwami od roku 1949.

5 „Przegląd Biblioteczny” - czasopismo bibliotekarskie, ukazujące się od roku 1927. Zob. Z. Gruszka: „Przegląd Biblioteczny”: monografia. Łódź-Warszawa 2012.

6 "Zagadnienia Informacji Naukowej" - czasopismo prezentujące problemy nauki o informacji, ukazujące się od roku 1972, następca periodyku „Biuletyn Ośrodka Dokumentacji i Informacji Naukowej", wydawanego w latach 1962-1971.

7 Analiza czasopism objęła następujące roczniki: „Bibliotekarz" - 1945-2015 (do numeru 5), „Poradnik Bibliotekarza” - 1945-2015 (do numeru 5), „Przegląd Biblioteczny” - 1945-2015 (do numeru 1), "Zagadnienia Informacji Naukowej” - 1964-2015 (do numeru 1). 
Teksty pogrupowano w dwa zasadnicze zespoły - artykuły metodyczne, zawierające konkretne rozwiązania i propozycje, oraz teksty reklamowe lub parareklamowe, w których poszczególne jednostki szkolnictwa wyższego przedstawiały swoją ofertę kształcenia. Najwięcej - 81 tekstów - opublikowano w „Bibliotekarzu”, 47 w „Przeglądzie Bibliotecznym”, $41 \mathrm{w}$ „Poradniku Bibliotekarza” i $21 \mathrm{w}$ "Zagadnieniach Informacji Naukowej". Wśród autorów znaleźli się zarówno pracownicy akademiccy, jak i praktycy bibliotekarstwa oraz studenci; część nazwisk powtarza się w każdym z wymienionych tytułów. Szczegółowej analizie poddano grupę tekstów stricte dotyczących modelu kształcenia i jego ewolucji - zarówno teksty ogólne podejmujące temat, jak i przykłady realizacji konkretnych założeń i programów w poszczególnych jednostkach kształcących bibliotekarzy i pracowników informacji.

Jako pierwszy dyskusję o kształceniu akademickim rozpoczął Jan Muszkowski, publikując w 1945 r. na łamach „Bibliotekarza”. Głównym założeniem kształcenia akademickiego powinno być szkolenie specjalistów-badaczy, oparte na trzech grupach zagadnień: 1) wytwarzanie dokumentów kultury, 2) obieg dokumentów kultury oraz 3) konsumpcja słowa drukowanego. Jako kierownik Katedry Księgoznawstwa i Bibliotekarstwa proponował trzy drogi kształcenia bibliotekarzy: 1) 2-letnie studia teoretyczne z praktyką po ukończeniu innego kierunku studiów; 2) absolutorium z jednej z grup zagadnień innego wydziału, a potem magisterium lub doktorat z nauk praktycznych (bibliotekarstwo, bibliografia, technika wydawniczo-księgarska) albo teoretycznych (historia drukarstwa, księgarstwa, bibliologia itp.); 3) w przypadku braku absolutorium z innego kierunku - studia 4-letnie. Wykłady i ćwiczenia mogłyby odbywać się w trzech grupach: 1) trzon specjalizacji bibliotekarsko-księgoznawczej (i tu: zagadnienia produkcji, obiegu i konsumpcji książki; teoria i historia bibliografii; wstęp do socjologii książki; bibliotekarstwo i historia bibliotek; teoria i metody badania czytelnictwa; pedagogika biblioteczna; zasady bibliologii; zagadnienia księgarstwa wydawniczego i sortymentowego; historia księgarstwa), 2) prowadzone na wszystkich wydziałach Uniwersytetu Łódzkiego lub wchodzące w zakres specjalizacji poszczególnych słuchaczy bądź wiążące się z nauką o książce (np. psychologia, historia kultury, historia piśmiennictwa), 3) zlecone w zakresie przedmiotów specjalnych i dziedzin pokrewnych (np. historia i technika drukarstwa, papiernictwo, introligatornia, opracowanie zbiorów specjalnych, archiwistyka i muzeologia).

Cztery lata później również na łamach „Bibliotekarza” J. Muszkowski zaprezentował nowe prądy w kształceniu bibliotekarzy ${ }^{9}$, przywołując

\footnotetext{
8 J. Muszkowski: Ksztatcenie bibliotekarzy. „Bibliotekarz” 1945 nr 2-3, s. 1-6.

9 J. Muszkowski: Nowe prądy w ksztatceniu bibliotekarzy. „Bibliotekarz” 1949 nr 1-2, s. 1-5.
} 
następujące propozycje: plany trzystopniowej edukacji - 4-letnie liceum, 1- lub 2-letnia szkoła specjalna oraz 11-trymestralne studia wyższe (sześć trymestrów w zakresie jednej dyscypliny, pięć - specjalizacja zawodowa) oraz trzy grupy przedmiotów egzaminacyjnych (nauka o książce, bibliotekarstwo, ewentualnie nauki pomocnicze historii). Pod koniec roku 1949 przedstawił pierwsze polskie przepisy studiów bibliotekarskich na poziomie uniwersyteckim ${ }^{10}$. Ich projekt ogłoszono 11 maja 1946 r. na zebraniu Rady Wydziału Humanistycznego Uniwersytetu Łódzkiego, wniosek uchwalono w czerwcu 1946 r., ustalając trzy grupy przedmiotów (nauka o książce, dwa przedmioty do wyboru z Wydziału Humanistycznego lub Wydziału Matematyczno-Przyrodniczego) oraz dwa języki obce w programie - jeden gruntownie w mowie i piśmie, drugi w czytaniu i rozumieniu. Projekt $\mathrm{w}$ formie ankiety międzyuniwersyteckiej zleconej przez Departament IV Ministerstwa Oświaty powrócił z ocenami pozytywnymi, zawierającymi propozycje niewielkich zmian. Ostatecznie kształcenie oparto na: Rozporządzeniu Ministra Wyznań Religijnych i Oświecenia Publicznego z dnia 2 kwietnia 1926 r. w sprawie programu studiów i egzaminów w zakresie historii na stopień magistra filozofii (Dz.Urz. M.W.R. i O.P. z 15 V 1926 nr 8 poz. 80) uzupełnionego przez Zarządzenie Ministra Oświaty z dnia 1 lutego 1949 r. (nr IV-SH-697/49) (Dz.Urz. M.O. $70 \quad$ z dnia 16 maja 1949 r. poz. 78) w sprawie specjalizacji bibliotekoznawczej i Rozporządzeniu Ministra W.R. i O.P. z dnia 26 marca 1926 r. w sprawie programu studiów i egzaminów w zakresie filologii polskiej na stopień magistra filozofii (Dz.Urz. M.W.R. i O.P. z 15 V 1926 nr 8 poz. 74), uzupełnionego przez Zarządzenie Ministra Oświaty z dnia 1 lutego $1949 \mathrm{r}$. (nr IV-O-15351/48). (Dz.Urz. M.O. z dnia 16 maja 1949 r. nr 5 poz. 77) w sprawie specjalizacji bibliotekoznawczej.

Siedem lat po przyjęciu programu, w 1956 r. pojawił się artykuł krytyczny autorstwa Stefanii Draczko ${ }^{11}, \mathrm{w}$ którym autorka nawoływała do reformy studiów wyższych, zarzucając programom przeładowanie treściami:

Absolwent tych studiów jest człowiekiem niedouczonym, nie ma opanowanej gruntownie, uprawniającej do stopnia naukowego żadnej dyscypliny oraz nie ma też wystarczającego zasobu praktycznych wiadomości bibliotekarskich $^{12}$.

${ }^{10}$ J. M[uszkowski]: Pierwsze polskie przepisy studiów bibliotekarskich na poziomie uniwersyteckim. „Bibliotekarz” 1949 nr 7-8, s. 137-140.

${ }^{11}$ S. Draczko: Kształcenie bibliotekarzy: artykut dyskusyjny. „Bibliotekarz” 1956 nr 6, s. $158-163$.

12 Ibidem, s. 159-160. 
Uważała także, że aby reforma miała sens, należy najpierw zbadać zapotrzebowanie bibliotek na pracowników o odpowiednich kwalifikacjach. Studia wyższe powinny przygotowywać kadrę nauki bibliotekoznawczej, reszta powinna skończyć 2-letnie wyższe szkoły bibliotekarskie, ewentualnie absolwenci innych kierunków studiów powinni uczestniczyć w specjalistycznych szkoleniach i po dwóch latach pracy w bibliotece zdawać egzamin lub odbyć roczny kurs w specjalnym ośrodku.

Ogólnego porównania oferty studiów bibliotekoznawczych na uniwersytetach polskich dokonała Krystyna Remerowa na łamach „Przeglądu Bibliotecznego" w 1958 r. ${ }^{13}$, wskazując obecność specjalizacji na III roku studiów 1 stopnia (210 godzin wykładów i ćwiczeń, 180 godz. praktyki wakacyjnej) i na 1,5-rocznych 2 stopnia (276 godz. wykładów i ćwiczeń, 90 godz. praktyk - 4 godz. tygodniowo), a także charakteryzując 1 stopień jako ogólnobibliotekarski, z następującymi grupami wiedzy: ogólna podbudowa studiów humanistycznych (np. logika, języki obce, filozofia); nauka o książce i bibliotece $\mathrm{w}$ ujęciu historycznym i teoretycznym wraz z praktyczną wiedzą (m.in. bibliotekarstwo, czytelnictwo, działy specjalne, bibliotekoznawstwo, bibliografia); przedmioty o charakterze materiałowym (historia i organizacja nauki), a IV i V rok uznając za pewnego rodzaju specjalizację z ofertą wykładów monograficznych. Zauważyła także, że praktyki powinny być zgodne z przedmiotami i wiedza, a "celem zaś praktyki jest wprowadzenie w normalny świat biblioteczny"14. Jako główne problemy wskazała autorka ubóstwo literatury naukowej, nikłą znajomość języków obcych przez studentów, zachowanie proporcji pomiędzy wiedzą naukową a zawodową oraz dysproporcje pomiędzy oczekiwaniami środowiska a efektami kształcenia. Wspomniała również o możliwości zorganizowania międzywydziałowej specjalizacji bibliotekoznawczej, pomimo tego że zakończone specjalistyczne kursy na III-IV roku nie przyniosły zadowalających rezultatów.

Interesujący głos zabrał w 1964 r. Kazimierz Maj ${ }^{15}$, postulując, by na studia bibliotekoznawcze przyjmować tylko absolwentów innych kierunków, aby mieli możliwość dokształcenia się z technologii pracy bibliotecznej. Przy ustalaniu programu studiów należy wziąć pod uwagę wszystkie typy bibliotek i ich specyfikę, dołączając do przedmiotów kształcenia także ekonomię, socjologię, historię kultury, dzieje oświaty i wychowania, filozofię, psychologię, pedagogikę, dydaktykę, organizację systemu oświaty, kultury i nauki.

${ }^{13}$ K. Remerowa: Studia bibliotekoznawcze na uniwersytetach polskich. „Przegląd Biblioteczny" 1958 z. 2-3, s. 115-130.

${ }^{14}$ Ibidem, s. 121.

${ }^{15}$ K. Maj: W sprawie kształcenia bibliotekarzy. „Bibliotekarz” 1964 nr 9, s. 259-264. 
Dwa lata później na łamach „Bibliotekarza” wydrukowano tekst Krystyny Remerowej ${ }^{16}$ dotyczący perspektyw rozwoju Katedry Bibliotekoznawstwa Uniwersytetu Warszawskiego ${ }^{17}$, w którym autorka zawarła również ogólne uwagi dotyczące kształcenia akademickiego bibliotekarzy. Wymieniła m.in. możliwość zatrudniania specjalistów na kilkugodzinne wykłady (kontakty środowiska akademickiego ze środowiskiem praktyków), bardzo ważną rolę praktyk w kształceniu, tworzenie specjalizacji zgodnych z zapotrzebowaniem rynku (na podstawie ankiety sprawdzającej, gdzie pracują absolwenci) oraz brak skryptów. Na brak nie tylko literatury, ale i samej bardzo ważnej specjalizacji - organizacja działalności bibliotecznej - zwrócił uwagę Jacek Wojciechowski ${ }^{18}$, przewidując wynikające z tego problemy w przyszłości.

W 1970 r. powrócił temat przygotowania specjalistycznej grupy bibliotekarzy z ukończonym innym kierunkiem studiów, który poruszył J. Muszkowski w pierwszym programowym tekście. Jan Baumgart ${ }^{19}$, przedstawiając studia międzywydziałowe, wskazał na ich główny cel: „wykształcenie studentów w zakresie bibliotekoznawstwa i informacji naukowej i przygotowanie ich do pracy bibliotekarskiej we wszystkich typach bibliotek"20. Były to studia dzienne, 4-semestralne dla studentów IV i V roku (lub III i IV studiów 4-letnich) innych kierunków. Na 600-godzinny program zatwierdzony przez Ministerstwo Oświaty i Szkolnictwa Wyższego, poza 2-tygodniowymi praktykami, złożyły się przedmioty teoretyczne i praktyczne (wstęp do nauki o książce i bibliotece, historia książki, historia drukarstwa i księgarstwa, historia bibliotek, bibliotekoznawstwo i bibliotekarstwo, bibliografia, dokumentacja i informacja naukowa). Jako ofertę dla bibliotekarzy pracujących przedstawił autor 4-semestralne studia podyplomowe zaoczne i wieczorowe, których program (również zatwierdzony przez MOiSzW) zawierał przedmioty podobne do omówionych wyżej studiów oraz bardziej specjalistyczne.

W 1971 r. do dyskusji metodycznej na temat systemu kształcenia bibliotekarzy dołączył w „Poradniku Bibliotekarza” z tekstem Włodzimie-

${ }^{16}$ K. Remerowa: Perspektywy rozwoju Katedry Bibliotekoznawstwa Uniwersytetu Warszawskiego. „Bibliotekarz” 1966 nr 5, s. 129-134.

17 Studia specjalistyczne bibliotekoznawcze zaczęły kształtować się w UW w $1951 \mathrm{r}$. - umieszczono wówczas na trzecich latach studiów filologicznych i historycznych I stopnia specjalistyczne wykłady bibliotekarskie, które w efekcie dawały dyplom zawodowy.

${ }^{18}$ J. Wojciechowski: Specjalność - organizacja działalności bibliotecznej. „Bibliotekarz” 1966 nr 12, s. 375-376.

${ }^{19}$ J. Baumgart: Międzywydziałowe i podyplomowe studia bibliotekoznawstwa na uniwersytetach w Polsce Ludowej. „Bibliotekarz” 1970 nr 1, s. 1-4.

${ }^{20}$ Ibidem, s. 2. 
rza Goriszowskiego ${ }^{21}$. Autor zaproponował następujący podział treści: I stopień - przygotowanie rzeczowe i metodyczne, częściowo teoretyczne; II stopień - 2-letnie seminarium magisterskie, np. z historii literatury dziecięcej, bibliotekoznawstwa, pedagogiki, psychologii lub socjologii.

Głos w 1971 r. zabrała także Helena Więckowska, przedstawiając system kształcenia bibliotekarzy na uniwersytetach polskich ${ }^{22}$. Przeanalizowawszy programy studiów, stwierdziła, że studia są dobrze rozłożone, kształcą dla wszystkich typów bibliotek, potrzebne jest jeszcze kształcenie specjalistyczne - ale na miejscu w bibliotece, do której trafi absolwent do pracy; dobrze by było, gdyby studia podyplomowe kształciły specjalistów, np. studium dla absolwentów studiów technicznych, medyków, biologów itp.; studia międzywydziałowe powinny objąć wszystkie kierunki studiów. Zaznaczyła jednak, że programy są przeładowane i za mało w nich treści współczesnych. Rok później ${ }^{23}$ podała sześć tematów do dyskusji: wspólne czy oddzielne kształcenie dla różnych typów bibliotek, selekcja kandydatów, reforma programów - więcej zagadnień międzynarodowych, języki obce, reforma metod nauczania, rekrutacja nauczycieli akademickich.

W 1975 r., opierając się na postulatach z Raportu o stanie biblioteki i prób ich realizacji, opublikowała kolejny tekst dotyczący kształcenia akademickiego bibliotekarzy ${ }^{24}$. W rozdziale VII raportu - Kadry biblioteczne i system ksztatcenia - zapisano następujące postulaty: konieczność unowocześnienia treści, podniesienie efektywności studiów, lepsze i szybsze przygotowanie pracowników, zmiana metod $-\mathrm{z}$ wykładowych na ćwiczebne, konieczność opracowania w Ministerstwie Nauki Szkolnictwa Wyższego i Techniki projektu jednolitego systemu studiów wyższych i przyspieszenie reformy programów w tym zakresie. Ministerstwo powołało Zespół Bibliotekoznawstwa i Informacji Naukowej. W styczniu 1974 r. rozpoczęto prace nad programem studiów, postulując: studia jednolite dla wszystkich typów bibliotek, studia magisterskie jako jeden z elementów systemu kształcenia bibliotekarzy; studia międzywydziałowe i podyplomowe;

${ }^{21}$ W. Goriszowski: Aktualizacja systemu ksztatcenia bibliotekarzy. „Poradnik Bibliotekarza" 1971 nr 3, s. 67-71. Wcześniej, np. w roku 1959, pojawiały się już w czasopiśmie reklamy studiów, np. w numerze 2-3 reklama zaocznych studiów z bibliotekoznawstwa na Wydziale Filologicznym Uniwersytetu Wrocławskiego, rekrutacja na rok 1959/1960 (3-4 strona okładki).

${ }^{22}$ H. Więckowska: System ksztatcenia bibliotekarzy na uniwersytetach polskich. „Przegląd Biblioteczny" 1971 z. 1-4, s. 230-241.

${ }^{23}$ H. Więckowska: Uniwersyteckie ksztatcenie bibliotekarzy. Problemy dyskusyjne. „Przegląd Biblioteczny" 1972 z. 1, s. 7-22.

${ }^{24}$ H. Więckowska: Akademickie kształcenie bibliotekarzy (postulaty Raportu o stanie bibliotek i próba ich realizacji). „Przegląd Biblioteczny” 1975 z. 3, s. 219-232. 
przygotowanie zawodowe, ale także naukowo-badawcze, elastyczność studiów. Projekty według tych wytycznych opracowały: Uniwersytet Warszawski, Uniwersytet Jagielloński, Uniwersytet Wrocławski oraz Uniwersytet im. Adama Mickiewicza. Autorka wskazała na dwie części projektu: ogólną dla wszystkich i specjalistyczno-wielokierunkową (III-IV rok) do wyboru, a także większy nacisk na praktyki oraz naukę języków obcych. Ponownie zaakcentowała profile kształcenia: program zmatematyzowany (więcej informacji) i program humanistyczno-społeczny (więcej historii), wnosząc także o nowoczesne metody nauczania.

Na problem kształcenia specjalistycznej grupy - nauczycieli-bibliotekarzy - zwróciła uwagę Krystyna Chacewicz ${ }^{25}$, pisząc o braku jednolitej koncepcji programowej i pomysłu na edukację tego typu bibliotekarzy. Jedynie Uniwersytet Wrocławski na ostatnim roku zamieścił $\mathrm{w}$ ofercie specjalizację z zakresu bibliotekarstwa szkolnego.

Ważną grupę tekstów stanowiły sprawozdania z konferencji, będących przykładem aktywnego udziału środowiska w grupowych, otwartych dyskusjach na temat kształcenia. Jednym z przykładów jest Sprawozdanie z sesji naukowej na temat dydaktyki bibliotekarstwa i informacji naukowej na poziomie wyższym, Warszawa 17-18 II $1976^{26}$ autorstwa Marcina Drzewieckiego ${ }^{27}$. Wśród głosów referentów H. Więckowska zwróciła uwagę, że programy studiów zmieniają się zgodnie z zapotrzebowaniem społecznym oraz omówiła różnice pomiędzy kształceniem matematyczno-społecznym (Warszawa, Kraków Poznań) a humanistycznym (pozostałe ośrodki); Władysław Zaczyński postulował aktywizację studentów i, co z nią związane, potrzebę odchodzenia od wykładów na rzecz konwersatoriów, seminariów i dyskusji, przy wykorzystaniu nowych środków technicznych do nauczania; Tadeusz Pilch mówił o edukacji permanentnej oraz konieczności wyposażenia absolwenta w umiejętności samokształcenia. Uczestnicy zwrócili uwagę na potrzeby akademickiego kształcenia przyszłych bibliotekarzy - nowe skrypty, pomoce naukowe, duże znaczenie praktyk, otoczenie opieką młodych ośrodków dydaktycznych (Olsztyn Kraków, Lublin, Słupsk). Delegat MNSzWiT - J. Woynarowska - zapewniła, że podręcznik bibliotekoznawstwa i informacji naukowej powstaje, są

${ }^{25}$ K. Chacewicz: Z zagadnień kształcenia i doskonalenia bibliotekarzy szkolnych w Polsce Ludowej. „Bibliotekarz” 1976 nr 4, s. 91-96.

${ }^{26}$ Organizatorzy: Komisja Bibliotekarzy i Dokumentalistów Sekcji Nauki ZNP oraz Sekcja Bibliotek Naukowych SBP.

${ }_{27}$ M. Drzewiecki: Sprawozdanie z sesji naukowej na temat dydaktyki bibliotekarstwa i informacji naukowej na poziomie wyższym, Warszawa 17-18 II 1976. „Bibliotekarz” 1976 nr 4, s. 100; sprawozdanie drugie dotyczące tego spotkania: K. Wyczańska: Nowoczesna dydaktyka na użytek studiów wyższych bibliotekoznawstwa i informacji naukowej. Seminarium 17-18 lutego 1976 r. „Zagadnienia Informacji Naukowej” 1976 nr 1, s. 185-188. 
też listy podręczników, skrypty zaś powinny powstawać na bieżąco. Jako największą słabość w kształceniu bibliotekarzy wskazała kadrę. Nadmieniła także, że uczelnie mogą zgłaszać zapotrzebowanie na pomoce dydaktyczne oraz że zostaną opracowane centralne programy (4-5 specjalizacji studiów), podjęte zostaną także starania o rozwiązanie problemów praktyk. Wskazała na konieczność częstszych spotkań metodycznych (pomimo braku pieniędzy), a studia międzywydziałowe wymieniła jako jedną $\mathrm{z}$ form kształcenia.

Zwięzłą charakterystykę studiów o profilu humanistycznym i matematyczno-społecznym przedstawiła $\mathrm{H}$. Więckowska ${ }^{28}$. I tak $\mathrm{w}$ profilu humanistycznym - 25\% godzin studiów przeznaczono na specjalizację (głównie książka i biblioteka); w profilu matematyczno-społecznym - 50\% studiów przeznaczono na specjalizację (głównie informacja naukowa i dokumentacja). Ponad to baza obejmowała trzy grupy przedmiotów: 1) przedmioty polityczno-społeczne obowiązujące na wszystkich kierunkach, 2) przedmioty ścisłe kierunkowe, 3) przedmioty uzupełniające i odpowiednio kształtujące treści przedmiotów kierunkowych. Przeanalizowawszy kilka programów zagranicznych, autorka stwierdziła, że w Polsce należy zmniejszyć liczbę wykładów na rzecz ćwiczeń i konwersatoriów.

W 1981 r. na łamach "Przeglądu Bibliotecznego" ukazało się sprawozdanie $^{29}$ z VIII Zjazdu Bibliotekarzy Polskich "Biblioteki dla wszystkich” (25-27 września 1980, Poznań), gdzie Sekcję IV poświęcono kształceniu i zawodowi bibliotekarza. Wśród referentów głos zabierał m.in. Krzysztof Migoń, przedstawiając w wystąpieniu Wyższe studia bibliotekoznawstwa $i$ informacji naukowej w Polsce w powiazaniu $z$ aktualnymi tendencjami światowymi ${ }^{30}$ ogólną charakterystykę obowiązujących programów. Pisał o dwóch modelach edukacji wyższej bibliotekoznawczej: studia o profilu matematycznym - kształcące pracowników bibliotek naukowych, fachowych, ośrodków informacji; profil humanistyczny - pracowników bibliotek publicznych, szkolnych, instytucji książki, bibliotek naukowych o profilu uniwersalnym. Za bardzo ważne uznał praktyki i specjalizacje, a na niekorzyść studiów uznał skrócenie ich trwania do 4 lat. Wymienił także zalecenia IFLA (The International Federation of Library Associations and Institutions) dotyczące kształcenia (automatyzacja, metody planowania, budownictwa i wyposażania) oraz zaakcentował potrzebę zapewnienia miejsc pracy, pragmatykę zawodową i konieczność uzależnienia limitów

${ }^{28}$ H. Więckowska: Nowe programy studiów bibliotekoznawstwa i informacji naukowej na tle światowych tendencji programowej. „Zagadnienia Informacji Naukowej” 1976 nr 1, s. 135-149.

29 Sekcja IV: Kształcenie i zawód bibliotekarza. Oprac. I. Kuczyńska. „Przegląd Biblioteczny" 1981 z. 3-4, s. 401-420.

${ }^{30}$ K. Migoń: Wyższe studia bibliotekoznawstwa i informacji naukowej w Polsce w powiazaniu z aktualnymi tendencjami światowymi. „Przegląd Biblioteczny” 1981 z. 3-4, s. 407-411. 
przyjęć na studia od perspektyw zatrudnienia. Podobnie jak poprzednicy zwrócił uwagę na niedostatki w kadrze i literaturze.

Zaangażowanie $\mathrm{w}$ omawianą tematykę przejawiały także kolegia redaktorskie analizowanych czasopism branżowych. 14 września 1981 r. w redakcji „Bibliotekarza” odbyła się dyskusja o aktualnych problemach zawodu bibliotekarskiego ${ }^{31}$. W spotkaniu uczestniczyli: Stefan Kubów (przewodniczący Zarządu Głównego Stowarzyszenia Bibliotekarzy Polskich, pracownik naukowo-dydaktyczny Instytutu Bibliotekoznawstwa Uniwersytetu Wrocławskiego), Eugenia Dabertowa (Biblioteka Uniwersytet im. A. Mickiewicza w Poznaniu), Danuta Konieczna (pracownik naukowo-dydaktyczny Wyższej Szkoły Pedagogicznej w Olsztynie), Olga Kossowska (studentka IV roku Studium dla Pracujących Instytutu Bibliotekoznawstwa i Informacji Naukowej Uniwersytetu Warszawskiego, przewodnicząca Samorządu Studentów Pracujących UW), Krzysztof Gonet (absolwent 1981 r. studiów stacjonarnych IBIN UW), Teresa Łapacz (Biblioteka Główna UW), Jakobina Kowalczyk (Biblioteka Narodowa, Instytut Bibliograficzny); redakcja: Jadwiga Kołodziejska (redaktor naczelna), Jerzy Maj (sekretarz redakcji), M. Drzewiecki (członek kolegium). Zebrani dyskutowali o czterech głównych zagadnieniach przedstawionych przez J. Kołodziejską: 1) czy praktyka biblioteczna determinuje i dy76 namizuje programy kształcenia, czy zachodzi między nimi spójność czy też obie te dziedziny funkcjonują niezależnie od siebie? 2) czy kształcenie bibliotekarzy jest perspektywiczne? 3) czy absolwenci są świadomi odrębności dziedziny? 4) czy środowisko naukowe bibliotekoznawców ma wpływ na kształt i realizowanie programów kształcenia? Podsumowując, stwierdzono, że sprawy płacowe, kwalifikacyjne i kształcenia powinny tworzyć spójny system, w związku z tym brak elit, a brak elit to obecny stan bibliotekarstwa i studiów. Wskazano też na potrzebę powiązania badań naukowych z dydaktyką ponieważ trudno bez tego mówić o rozwoju dziedziny.

Poważne zastrzeżenia do kształcenia akademickiego wyraził Marian Walczak, który w tekście z roku $1982^{32}$ stwierdził, że liczba ośrodków akademickich (było ich wówczas 14) powinna być zmniejszona, ponieważ nie mają one zaplecza naukowego, przygotowanej kadry, bazy dydaktycznej i warsztatu naukowego; chętniej zatrudniani są absolwenci szkół średnich lub studium, ponieważ mają większą wiedzę praktyczną. Poza tym za dużo już jest absolwentów szkół wyższych - do bibliotek wiejskich wystarczy wykształcenie średnie. Uważał także, że obecnie proponowa-

31 Aktualne problemy zawodu bibliotekarskiego (Dyskusja w Redakcji). „Bibliotekarz” 1981 nr 6, s. 129-143.

32 M. Walczak: O spójny system kształcenia bibliotekarzy. „Bibliotekarz” 1982 nr 1, s. 17-20. 
ne specjalizacje są złe - nie powinno kształcić się pod typ biblioteki, lecz zgodnie z dziedzinami pracy bibliotecznej, np. praca z dziećmi, bibliografia, a tematy prac magisterskich należy skorelować z praktykami i przyszłym miejscem pracy. Na oczywistą potrzebę sprzężenia kształcenia z polityką zatrudniania zwrócił także uwagę Jan Sójka ${ }^{33}$.

W roku 1983 ukazał się specjalny numer "Przeglądu Bibliotecznego”, w całości poświęcony akademickiemu kształceniu bibliotekarzy ${ }^{34}$. Poza przeglądem i oceną literatury dydaktycznej (s. 173-257), kilkoma artykułami oraz zestawieniem programów studiów z ośrodków polskich, zamieszczono w nim także opracowane przez Jadwigę Ćwiekową tezy do dyskusji o kształceniu i doskonaleniu bibliotekarzy ${ }^{35}$. Wśród uwag dotyczących szkolnictwa wyższego (poza nim wymieniono także średnie i podyplomowe) w dyskusji pojawiła się propozycja wprowadzenia co najmniej rocznych stażów w bibliotekach dla pracowników kształcących przyszłych bibliotekarzy. Komisja ds. Kształcenia i Doskonalenia Zawodowego przy Zarządzie Głównym SBP zalecała także, by studia zaoczne były uruchamiane $\mathrm{w}$ wybranych placówkach i trwały o pół roku dłużej niż studia stacjonarne. Podobnież trzy najlepsze ośrodki powinny kształcić bibliotekarzy do pracy w bibliotekach specjalnych na studiach międzywydziałowych (dla studentów III, IV i V roku innych kierunków). Również studia podyplomowe należałoby, według Komisji, podzielić na dwa rodzaje: 3-4-semestralne dla niebibliotekoznawców oraz 2-semestralne, specjalistyczne (np. z zarządzania, bibliografii, czytelnictwa), dla czynnych bibliotekarzy. Za plus ówczesnych programów kształcenia uznano ich zróżnicowanie, postulując jednocześnie zwiększenie liczby specjalizacji. Propozycje opracowane przez Komisję zakończono stwierdzeniem:

Przy różnorodności struktur organizacyjnych bibliotek w kraju i rozległości ich zadań funkcjonalnych oraz przy bogactwie księgozbiorów potrzebne są wysoko kwalifikowane, mądre i twórcze kadry biblioteczne ${ }^{36}$.

Krytycznym głosem w dyskusji o formie kształcenia bibliotekarzy był także tekst Grzegorza Chmielewskiego ${ }^{37}$. Autor stwierdził, że niedoświadczona kadra prowadzi ćwiczenia (np. asystenci, którzy nigdy w bibliotece nie pracowali), a praktyczne bibliotekarstwo nauczane jest za wcześnie

${ }^{33}$ J. Sójka: System kształcenia bibliotekarzy - propozycje docelowego modelu. „Bibliotekarz” 1984 nr 6-7, s. 172-178.

34 „Przegląd Biblioteczny” 1983 z. 2-3.

35 Tezy do powszechnej dyskusji nad wspótczesnym modelem kształcenia i doskonalenia zawodowego bibliotekarzy. Oprac. J. Ćwiekowa. „Przegląd Biblioteczny” 1983 z. 2-3, s. 301-304.

${ }^{36}$ Ibidem, s. 304.

${ }^{37}$ G. Chmielewski: Głos w dyskusji na temat kształcenia bibliotekoznawców. „Przegląd Biblioteczny" 1983 z. 4, s. 411-413. 
(np. na I i II roku), czego efektem są absolwenci niepamiętający niczego z zajęć; specjalizacje - powinny być dopiero po ukończeniu studiów, a w ich trakcie dużo praktyk; z programów wyłączyć należy literaturę, psychologię itp. i skupić się na bibliotekoznawstwie oraz wprowadzić 2-letnie studia dla pracujących, specjalizacyjne (np. zagadnienia wydawnicze i księgarskie, informacja naukowa, bibliografia itp.), a kształcenie zawodowe połączyć ze specjalizacjami po studiach.

Dwa lata później, również na łamach „Przeglądu Bibliotecznego”, niemalże cały numer poświęcono kształceniu akademickiemu bibliotekarzy szkolnych $^{38}$. Poza trzema tekstami: Aleksandry Niemczykowej o specjalizacji biblioteki szkolne i pedagogiczne w Instytucie Bibliotekoznawstwa i Informacji Naukowej Uniwersytetu Warszawskiego (s. 167-184), Jadwigi Andrzejewskiej o przygotowywaniu do pracy nauczycieli-bibliotekarzy w Instytucie Bibliotekoznawstwa Uniwersytetu Wrocławskiego (s. 185-200) oraz M. Drzewieckiego o kształceniu tej grupy zawodowej poza granicami Polski (s. 201-218), zamieszczono także relację z sesji tematycznej zorganizowanej przez ośrodek warszawski (wygłoszono na niej referaty opublikowane w tym numerze czasopisma), która miała miejsce 13 kwietnia 1984 r. w Warszawie (s. 211-218). Rozmówcy poruszyli kwestię praktyk i przygotowania dydaktycznego studentów, postulując zwiększenie liczby realnych kontaktów z biblioteka, ,aby oszczędzić absolwentowi szoku w zetknięciu z rzeczywistością" ${ }^{39}$. Podobnie jak w poprzednim numerze tematycznym, i tu pojawiły się głosy o konieczności utworzenia studiów podyplomowych ogólnobibliotekarskich lub specjalistycznych, dla różnych typów placówek bibliotecznych.

W tym samym roku ukazał się w "Przeglądzie Bibliotecznym” tekst Juliana Gałczyńskiego ${ }^{40}$ traktujący o modelu absolwenta studiów bibliotekoznawstwa i informacji naukowej. Autor postulował w nim oddzielenie kształcenia bibliotekarzy dla bibliotek publicznych, szkolnych, pedagogicznych oraz humanistycznych bibliotek naukowych od kształcenia dla bibliotek naukowych o profilu ścisłym i ośrodków informacji naukowej, technicznej i ekonomicznej, którzy powinni kształcić się na studiach międzywydziałowych lub na wydziałach technicznych, uzyskując tytuł magistra inżynierii informacji naukowej z odpowiednią specjalnością.

Również w 1985 r. na łamach „Poradnika Bibliotekarza” pojawił się artykuł dyskusyjny M. Drzewieckiego ${ }^{41}$. Autor pochwalił różnorodność

38 „Przegląd Biblioteczny” 1985 z. 2, s. 165-226.

39 Ibidem, s. 215.

40 J. Gałczyński: O model absolwenta studiów bibliotekoznawstwa i informacji naukowej. „Przegląd Biblioteczny” 1985 z. 1, s. 55-62.

${ }^{41}$ M. Drzewiecki: Kształcenie $i$ doskonalenie zawodowe bibliotekarzy sieci bibliotek publicznych. Wybrane zagadnienia. Artykut dyskusyjny. „Poradnik Bibliotekarza” 1985 nr 4, s. 135-138. 
i odmienność programów kształcenia w poszczególnych ośrodkach akademickich, jednak, ukuwszy termin „wszystkoizm”, zarzucił nadmiarowość treści kształcenia, w myśl zasady, że wszystko się studentowi przyda.

Numery kolejne (z lat 1986-1988) „Poradnika Bibliotekarza” stały się miejscem wielogłosowej polemiki. Tekstem rozpoczynającym wymianę poglądów był artykuł Marka Nahotki ${ }^{42}$, zawierający określenie absolwenta bibliotekoznawstwa mianem „chłopca do bicia”, który, zestawiając naukę ze studiów z praktyką i rzeczywistością popada we frustrację potęgowaną niskimi zarobkami. Absolwent ten, według autora, nie ma także wiedzy praktycznej, ,jest złym pracownikiem", a studia stają się konglomeratem wiedzy wszelakiej (podobną tezę postawił w roku poprzednim M. Drzewiecki). Problemem, na który zwrócił uwagę M. Nahotko, było zatrudnianie wszystkich chętnych osób, niekoniecznie wykształconych.

$\mathrm{Na}$ tego typu uwagi zareagował m.in. M. Walczak, pisząc w numerze 1 z roku $1987^{43}$, że cieszy się z ożywienia dyskusji, nie przychylił się jednak do opinii M. Nahotki. Po raz kolejny zadał pytanie, czy potrzebne są aż 5-letnie studia i czy przygotowują one dobrze w sposób praktyczny. Po raz kolejny także zarzucił programom przeładowanie, cytując za M. Nahotką określenie „konglomeraty” z różnych dyscyplin, przy braku skryptów, wykładowców-bibliotekoznawców i wykładowców-praktyków. Wskazał także na problem nie tylko wykształcenia kadr bibliotekarskich, lecz także ich wychowania w odpowiednim podejściu do zawodu i jego społecznym charakterze.

Do kwestii poruszonych przez Marka Nahotkę odniósł się także Henryk Hollender ${ }^{44}$, konstatując, że właściwie nie wiadomo, czego uczymy, nie dyskutuje się o kadrach i programach, a te drugie powinny stale się zmieniać, choć są tylko jednym z elementów dobrego kształcenia. Nie powinno się ich także rozdmuchiwać w myśl zasady, że wszystko może się przydać. Poparł postulat dotyczący zatrudniania praktyków, ale takich, którzy będą też dobrymi wykładowcami, ponieważ teoria i praktyka powinny iść w parze.

Głos w sprawie zabrał M. Drzewiecki ${ }^{45}$, negując stwierdzenie M. Walczaka o bibliotekarzach jako najsłabszych ogniwach w bibliotece. Podał także zagraniczne, sprawdzone przykłady podziału na pracowników merytorycznych i technicznych. Zgodził się, że, owszem, absolwent technikum

${ }^{42}$ M. Nahotko: Kształcenie bibliotekarzy na poziomie wyższym - mity i rzeczywistość. „Poradnik Bibliotekarza" $1986 \mathrm{nr}$ 7-8, s. 3-5.

${ }^{43}$ M. Walczak: Bibliotekoznawca czy bibliotekarz? „Poradnik Bibliotekarza” 1987 nr 1, s. 9-12.

${ }^{44}$ H. Hollender: Po pierwsze nie szkodzić. „Poradnik Bibliotekarza” 1987 nr 4, s. 6-9.

${ }^{45}$ M. Drzewiecki: Nie mylić skutków z przyczynami. „Poradnik Bibliotekarza” 1987 nr 5, s. 4-5. 
będzie bieglejszy w pracy niż absolwent studiów, który jednak wynosi ze studiowania coś więcej. Poza tym edukacja na poziomie wyższym przygotowuje do zawodu, a praktyki - do jego wykonania, stąd kolejny już nacisk na praktyczną naukę. Autor pozytywnie ocenił różnorodność w programach studiów, które ciągle ewoluują, zanegował jednak stwierdzenie, jakoby bibliotekarze byli najsłabszymi ogniwami w bibliotekach.

Również przywoływany już Z. Żmigrodzki ${ }^{46}$ skomentował tekst M. Walczaka, uważając, że obecność innych nauk na studiach bibliotekoznawczych jest pożądana, jako przykład podał mikrobiologa niezbędnego przy konserwacji. Stwierdził także, że zły stan bibliotek to nie wina bibliotekarzy, lecz często organów prowadzących.

Do obrony studiów wyższych bibliotekoznawstwa i informacji naukowej dołączył w tym samym numerze czasopisma także Lech Michalski ${ }^{47}$, zaznaczając, że bibliotekoznawców na studiach nie kształci się do prostych prac bibliotekarskich, lecz do organizowania i koordynowania; absolwent jest potencjalnym teoretykiem i twórcą bibliotekarstwa współczesnego. Kształcenie akademickie pozwala na uzyskanie wysoko wykwalifikowanych pracowników, którzy powinni otrzymywać pracę w bibliotekach. Polemiczny do artykułu Walczaka tekst Cecylii i Juliana Gałczyńskich, zamieszczono w numerze $10-11$ z 1987 r. ${ }^{48}$ Autorzy rozgraniczyli kształ80 cenie na potrzeby bibliotek publicznych i szkolnych, które powinno się odbywać na uniwersytetach i wyższych szkołach pedagogicznych, oraz bibliotek specjalnych - w ramach wspomnianych już studiów międzywydziałowych. Nie mniej jednak uważali, że absolwent bibliotekoznawstwa ma tylko wiedzę teoretyczna, jest formalnym specjalista, nie ma wiedzy specjalistycznej, merytorycznej.

Powracając do problemu, L. Michalski ${ }^{49}$ stwierdził, że studia muszą być formalne, bo przepisy jasno określaja, kto może pracować w bibliotekach; niebibliotekoznawcy często traktują bibliotekę jako tylko przystań na chwilę, bibliotekoznawcy celowo się dla niej szkolili. Kształcenie bibliotekarzy-dziedzinowców uznał za pozbawione sensu (lekarz-bibliotekarz, rolnik-bibliotekarz...), lepiej, jego zdaniem, zrobić podyplomowe kształcenie dziedzinowe (jak specjalizacje w służbie zdrowia), a nie finezyjne wielokierunki. Tym samym trzeba wyważyć proporcje pomiędzy bibliotekarzem a potrzebną wiedzą specjalistyczną podporządkowaną bibliotekarstwu.

46 Z. Żmigrodzki: Daleko od obiektywizmu. „Poradnik Bibliotekarza” 1987 nr 5, s. 5-6.

${ }^{47}$ L. Michalski: Dlaczego się nie zgadzam. „Poradnik Bibliotekarza” 1987 nr 5, s. 6-8.

${ }^{48}$ C.Z. Gałczyńska, J. Gałczyński: Różnorodne jest piękne (i pożyteczne). „Poradnik Bibliotekarza" 1987 nr 10-11, s. 9-11.

${ }^{49}$ L. Michalski: Jeszcze raz o tym samym. „Poradnik Bibliotekarza” 1988 nr 1, s. 20-21. 
Do tekstu M. Walczaka odniósł się także Andrzej Gawrońskij ${ }^{50}$, negując potrzebę powołania Wyższej Szkoły Zawodowej Bibliotekarstwa i podkreślając dobrą jakość kształcenia wyższego, do którego jednak powinno zatrudniać się więcej praktyków. Odrzucił także rozdzielenie przez M. Walczaka nauczania uniwersyteckiego, opartego na studiowaniu, od nauczania zawodowego, twierdząc, iż te dwie formy współistnieją.

W numerze 7-8 z roku 1987 zamieszczono odpowiedź M. Nahotki ${ }^{51}$ dla M. Walczaka, w której autor stwierdził m.in., że bibliotekoznawcy będący bibliotekarzami są kształceni na każdej uczelni.

$\mathrm{W}$ innych swoich tekstach $\mathrm{M}$. Walczak zwracał uwagę na brak badań dotyczących absolwentów, skryptów, pomocy i opracowań, umocnień prawnych zatrudniania na stanowiska w bibliotekach, zauważał przewagę tematyki historycznej $\mathrm{w}$ tematach prac magisterskich i doktorskich ${ }^{52}$; pisał o potrzebie funkcjonowania studiów międzywydziałowych, niedrożności wszystkich stopni kształcenia; wysunął także postulat o potrzebie nowych programów ze skorelowanymi treściami, opracowywanych przez niezależnych autorów, a następnie zrecenzowanych i poddanych pod dyskusję ${ }^{53}$.

Marian Walczak sformułował jeszcze inne negatywne oceny pod adresem kształcenia akademickiego ${ }^{54}$, wskazując dysproporcje programowe (za dużo teorii, za mało praktyki), coraz gorsze przygotowanie do pracy z czytelnikiem, słabszą znajomość literatury i coraz większy brak zamiłowania do pracy w bibliotece, brak poczucia wartości zawodu, częste zmiany zawodu z bibliotekarskiego na inne. Skrytykował także podział na studia dzienne i zaoczne, wskazując na coraz większe dysproporcje pomiędzy nimi, brak wykładowców, potrzebę rewizji programów nauczania przestarzałych i nieskorelowanych. W artykule z $1990 \mathrm{r}$. autor ten stwierdził, że zastanowienia wymaga aż pięcioletni okres kształcenia bibliotekarzy na studiach wyższych, ponieważ cenniejsi dla bibliotek są przysposobieni do zawodu absolwenci innych kierunków humanistycznych ${ }^{55}$. $\mathrm{Z}$ propozycją zmian $\mathrm{w}$ poziomach kształcenia bibliotekarzy powrócił

${ }^{50}$ A. Gawroński: Kształcenie bibliotekarzy (głos w dyskusji). „Poradnik Bibliotekarza” 1987 nr 5, s. 10-12.

${ }^{51}$ M. Nahotko: Bibliotekoznawca to bibliotekarz. „Poradnik Bibliotekarza” 1987 nr 7-8, s. 12-13.

${ }^{52}$ M. Walczak: Problemy ksztatcenia pracowników dla bibliotek. „Bibliotekarz” 1984 nr 9-10, s. 257-261.

${ }_{53}$ M. Walczak: Koncepcja systemu kształcenia, dokształcania i doskonalenia zawodowego bibliotekarzy w Polsce. „Bibliotekarz” 1986 nr 9, s. 3-14.

${ }^{54}$ M. Walczak: Perspektywa kształcenia bibliotekarzy do końca stulecia. „Bibliotekarz" 1988 nr 7-8, s. 3-7.

${ }^{55}$ M. Walczak: Wizja ksztatcenia bibliotekarza nowoczesnego. „Bibliotekarz” 1990 nr 5-6, s. 11-14. 
w $1994 \mathrm{r}^{56}$, stwierdzając słabe akademickie przygotowanie bibliotekarzy (warsztatu bibliotekarskiego uczących się dopiero w pracy) i postulując nadanie dwuletnim szkołom pomaturalnym statusu wyższych szkół zawodowych, oraz konkludując, że wszystkie poziomy kształcenia mogą być, o ile będą: ,jjednością nakierowaną na kreowanie zawodu bibliotekarza i pracownika informacji bibliotecznej" 57 .

W roku 1987 ukazał się monograficzny numer „Bibliotekarza” - Stan i perspektywy bibliotekarstwa polskiego do roku 2000 58 , w którym znalazł się także rozdział poświęcony kształceniu akademickiemu ${ }^{59}$. Przywołując nieco historii, wskazano na znaczne zwiększenie się liczby ośrodków akademickich w latach siedemdziesiątych ${ }^{60}$, pomimo braków kadrowych (większość wykładowców to nie bibliotekoznawcy, lecz historycy, literaturoznawcy, kulturoznawcy i księgoznawcy). W drodze poszukiwań i ewolucji wykształciły się dwa modele kształcenia - humanistyczno-społeczny i matematyczno-społeczny, zaś wśród specjalizacji: informacja naukowa, bibliotekarstwo szkolne, historia książki i bibliotek, bibliotekarstwo, księgarstwo, bibliografia, edytorstwo i bibliologia. Zauważono, że niestety, pomimo postulatów środowiska, nie kształci się w kierunku systemów bibliotecznych, komputeryzacji, ekonomizacji pracy, kierowania i zarządzania czy metodyki pracy. Kuleje również techniczna i osobowa 82 strona studiów (brak odpowiedniego wyposażenia sal i instytutów, brak literatury i brak znajomości języków obcych, a także odpowiedniej kadry). Pod rozwagę podał autor zasadność istnienia aż 14 ośrodków wyższych kształcących bibliotekarzy.

Rok 1993 przyniósł pesymistyczny obraz upadku prestiżu zawodu oraz propozycje poprawy sytuacji autorstwa Jadwigi Kołodziejskiej ${ }^{61}-$ zli- $^{-}$ kwidowanie nadmiaru szkół średnich, umocnienie szkół wyższych oraz umocnienie współpracy pomiędzy bibliotekami a ośrodkami kształcącymi i specjalistami.

W 1994 r. pojawił się artykuł (jeden z nielicznych głosów absolwentów) Anny Ogonowskiej i Małgorzaty Opalińskiej, w którym autorki przedstawiły swoją propozycję programu studiów dla specjalizacji in-

${ }^{56}$ M. Walczak: Poszukiwanie nowych form ksztatcenia i doskonalenia zawodowego bibliotekarzy. „Bibliotekarz” 1994 nr 11-12, s. 10-15.

${ }^{57}$ Ibidem, s. 15.

58 „Bibliotekarz” $1987 \mathrm{nr} 7-8$.

59 Akademickie ośrodki kształcenia bibliotekarzy. „Bibliotekarz” 1987 nr 7-8, s. 48-51.

${ }^{60}$ W 1987 r. były to uniwersytety w Łodzi, Poznaniu, Warszawie, Wrocławiu, Toruniu, Krakowie, Gdańsku, Katowicach i Lublinie oraz wyższe szkoły pedagogiczne w Olsztynie, Zielonej Górze, Szczecinie, Kielcach i Bydgoszczy.

${ }^{61}$ J. Kołodziejska: Wybrane problemy kształcenia bibliotekarzy "Bibliotekarz" 1993 nr 7-8, s. 20-24. 
formacja naukowa ${ }^{62}$, dzieląc go na sześć bloków. Blok I - podstawy wiedzy zawodowej (terminologia także obcojęzyczna, sytuacja i zagadnienia związane z dokumentami, biblioteką i informacją naukową); II - podstawy każdej ze specjalizacji z wykazem problemów danego kierunku (historia książki i bibliotek, czytelnictwo, działalność informacyjna bibliotek, użytkownicy bibliotek, nowe technologie w bibliotekach, bibliofilstwo, edytorstwo); III - wiedza ogólnokształcąca (logika, komunikacja, naukoznawstwo, zarządzanie, statystyka, dwa języki obce, wychowanie fizyczne, metodologia); IV - wykłady monograficzne (wąskospecjalizacyjne, np. zaliczane jako udział w konferencjach - pewna liczba takich kursów w całym kształceniu); V - przedmioty specjalistyczne (matematyczne podstawy systemów informacyjno-wyszukiwawczych, lingwistyczne podstawy SIW, elementy analizowania i projektowania SIW, języków informacyjno-wyszukiwawczych, heurystyka, organizacja ośrodka informacji, projektowanie baz danych, automatyzacja bibliotek, seminarium magisterskie); VI - praktyka - centralna część specjalizacji - powinna trwać pół roku. Całość to ok. 4000 godz./5 lat = 2000 godz. zajęć +2000 godz. pracy samodzielnej, z czego $25 \%$ to podstawy wiedzy zawodowej, $25 \%$ specjalizacja, $20 \%$ praktyka, $15 \%$ zajęcia ogólnokształcące, $10 \%$ wprowadzenie w specjalizację, 5\% wykład monograficzny. Autorki zwróciły uwagę, że coraz więcej powinno być prac magisterskich o charakterze praktycznym.

W roku 1995, dzięki artykułowi Barbary Sosińskiej-Kalaty, pojawił się temat dążenia w Polsce do standardów światowych ${ }^{63}$. Jak zauważyła autorka, także działalność bibliotek i kształcenie bibliotekarzy powinny nadążać za zmianami w społeczeństwie, nauce, technologii, polityce, ekonomii i edukacji. Aby owo nadążanie było możliwe, potrzeba standardów kształcenia, które pozwolą na określenie modelu i założeń podstawowych kształcenia, wymagań rekrutacyjnych, treści programowych dostosowanych do pragmatyki zawodowej, wymagań dla konkretnych poziomów kształcenia (zarówno pod względem kadry, jak i wyposażenia). Dzięki nim możliwe są do osiągnięcia spójność kształcenia i porównywalność dyplomów, a także wysoki poziom kształcenia i ochrona zawodu bibliotekarskiego. Wymieniając standardy zagraniczne (m.in. języki obce, prestiż zawodu, zarządzanie informacją umiejętności komunikacyjne, integracja treści współczesnych i historycznych, marketing i tworzenie różnych treści różnymi technikami, kreatywność, podnoszenie kwalifikacji, pogłębianie specjalizacji, misja zawodu - pedagog i organizator dostępu do informacji,

${ }^{62}$ A. Ogonowska, M. Opalińska: Nasz projekt programu studiów dla specjalizacji informacja naukowa. "Bibliotekarz” 1994 nr 2, s. 17-25.

${ }^{63}$ B. Sosińska-Kalata: Perspektywy kształcenia bibliotekarzy - dążenie do standardów światowych. „Bibliotekarz” 1995 nr 7-8, s. 5-9. 
pogłębiający świadomość informacyjną społeczeństwa), wskazała jednocześnie główne mankamenty warunków polskich (m.in. zmniejszenie liczby godzin lektoratów, brak przepisów, niepowiązanie nauczania z pragmatyką zawodu), które uniemożliwiały wprowadzenie europejskiego poziomu kształcenia wyższego w zakresie bibliotekoznawstwa i informacji naukowej.

W tym samym numerze opublikowano także tekst Marii Kocójowej dotyczący międzynarodowych wytycznych UNESCO/IFLA/EUCLID ${ }^{64}$, będący sprawozdaniem ze spotkania w Bratysławie ekspertów z 20 krajów (14-18 listopada 1994). W celu ukazania istoty zaleceń dotyczących kształcenia z zakresu informacji naukowej autorka wymieniła następujące punkty - wnioski z obrad: 1) konieczność priorytetu kształcenia uniwersyteckiego; 2) przeprowadzeniebadańrynku zatrudnienia absolwentówbibliotekoznawstwa i informacji naukowej i po nich przystosowanie studiów do oczekiwań; 3) dostosowanie studiów do rewolucji technicznych i organizacyjnych; 4-5) nowoczesne techniki w nauczaniu, ale i nauczane; 6) zapewnienie odpowiedniego wyposażenia ośrodków kształcących; 7) szkolenia nauczycieli akademickich; 8) więcej języków obcych; 9) współpraca międzynarodowa dwustronna w zakresie kształcenia; 10) centra uniwersyteckie z doskonałym wyposażeniem dla kierunków bibliotekoznawstwo i informacja naukowa.

O nowoczesnym modelu kształcenia bibliotekarzy rozmawiano także na konferencji II Forum Stowarzyszenia Bibliotekarzy Polskich nt. "Ksztatcenie Bibliotekarzy dla Przyszłości". Jachranka, 22-24 października 1995 r., sprawozdanie z której zamieszczono w numerze 7-8 z roku 1996 ${ }^{65}$. Za konieczne uznano: wypracowanie modelu bibliotekarza przyszłości, jednolite wzorce kształcenia zgodne ze standardami międzynarodowymi, dostosowanie programów nauczania do nowych realiów bibliotecznych, zgodność pomiędzy profilem absolwenta a oczekiwaniami rynku pracy, kontakty z zagranicznymi ośrodkami; więcej szkoleń i studiów podyplomowych rozwijających konkretne umiejętności; drożność pomiędzy poziomami kształcenia, określenie statusu i uprawnień absolwentów, kształcenie zgodne ze strategią rozwoju bibliotek, współpraca pomiędzy ośrodkami kształcenia i czynnymi bibliotekarzami.

W 1995 r. po raz kolejny wyraził swoje poglądy na temat kształcenia bibliotekarzy i pracowników informacji naukowej J. Wojciechowski ${ }^{66}$, pisząc o dezorientacji, braku całościowego spojrzenia (praktycy nie mają

${ }^{64}$ M. Kocójowa: Przyszłość kształcenia specjalistów informacji naukowej w krajach postkomunistycznych w świetle Generalnego Programu Informacji (zalecenia UNESCO/IFLA/EUCLID). „Bibliotekarz” 1995 nr 7-8, s. 9-12.

${ }^{65}$ Rekomendacje II Forum Stowarzyszenia Bibliotekarzy Polskich nt. "Kształcenie Bibliotekarzy dla Przyszłości”. Jachranka, 22-24 października 1995 r. „Bibliotekarz” 1996 nr 7-8, s. 25-27.

66 J. Wojciechowski: O kształceniu bibliotekarzy. „Bibliotekarz” 1995 nr 10, s. 3-5. 
pojęcia o kształceniu, teoretycy o praktyce, chyba że w wąskiej działce). Autor pisał, że uczy się w oderwaniu od bibliotek, nadal pielęgnując natłok treści historycznych w programach, próbuje się być nowoczesnymi, umożliwiając absolwentom studiów 3-letnich każdego kierunku uzyskanie tytułu magistra bibliotekoznawstwa i informacji naukowej po 2-letnich studiach bibliotekoznawstwa. Pewną nadzieję budzi, według autora, akredytacja, ta jednak musi być przeprowadzona sensownie.

Nowe możliwości w kształceniu bibliotekarzy zaprezentowała B. Sosińska-Kalata ${ }^{67}$, wskazując jednocześnie trzy największe problemy: nieekonomiczność systemu edukacji w Polsce, niedostosowanie programów do gospodarki rynkowej i brak drożności pomiędzy poszczególnymi rodzajami kształcenia. Od początku lat dziewięćdziesiątych zachodzą zmiany w programach i zasadach kształcenia, coraz większy nacisk kładzie się na nowoczesne techniki informacyjne, nowoczesne metody organizacji pracy, funkcjonowanie bibliotek $\mathrm{w}$ demokracji i gospodarce wolnorynkowej; dokonuje się rewizji proporcji pomiędzy wiedzą metodologiczną a faktograficzna, z naciskiem na umiejętność samodzielnego zdobywania wiedzy i rozwiązywania problemów. Jako przykłady i wzorce zagraniczne podaje m.in. zalecenia UNESCO, EUCLID, ALA, ASIS oraz zalecenia krajowe. Według autorki istnieje potrzeba ustalenia relacji pomiędzy szkolnictwem średnim i wyższym. Nowy system kształcenia bibliotekarzy powinien objąć: 1) absolwentów ogólnokształcących szkół średnich, 2) absolwentów bibliotekarskich i dokumentacyjnych szkół pomaturalnych, 3) absolwentów bibliotekoznawczych szkół wyższych, 4) absolwentów szkół wyższych na innych kierunkach, 5) osoby dysponujące doświadczeniem zawodowym w bibliotekarstwie i działalności informacyjnej, 6) osoby bez doświadczenia. System kształcenia powinien być drożny i elastyczny, przy czym bardziej racjonale jest wydłużenie trybu zaocznego (wzorem innych państw), niż utrzymywanie, że w czasie trzy razy krótszym student zaoczny będzie tak samo wykształcony jak dzienny. Programy powinny być efektywne, skondensowane, dające konkretne uprawnienia. Studia 3-letnie (bakalaurackie) - pomysł nowy, ale to, według autorki, ślepy zaułek, ponieważ brak m.in. regulacji prawnych dot. uprawnień zawodowych absolwentów nauki 3-letniej.

W 1998 r. na łamach ZIN-u zamieszczono tekst autorstwa M. Drzewieckiego i B. Sosińskiej-Kalaty ${ }^{68}$, w którym autorzy przedstawili kwestię

${ }^{67}$ B. Sosińska-Kalata: Nowe możliwości kształcenia bibliotekarzy (1). „Poradnik Bibliotekarza" 1996 nr 9, s. 1-4; eadem, Nowe możliwości kształcenia bibliotekarzy (2), ibidem nr 10, s. $1-4$.

${ }^{68}$ M. Drzewiecki, B. Sosińka-Kalata: Europejskie standardy ksztatcenia a restrukturyzacja polskiego systemu edukacji bibliotekarzy i pracowników informacji (program TEMPUS - JEP -12165-97). „Zagadnienia Informacji Naukowej” 1998 nr 2, s. 87-99. 
europejskich standardów kształcenia i restrukturyzacji polskiego systemu edukacji bibliotekarzy i pracowników informacji. Analizując obydwa zagadnienia, stwierdzili, że powinno się zadbać (jak w krajach Unii Europejskiej) o ekonomiczność kształcenia (m.in. poprzez określenie kwalifikacji po każdym poziomie kształcenia), drożność pionową, upowszechnienie wykształcenia wyższego jako pełnego. Ówcześnie w Polsce funkcjonowały szkoły: 2-letnie pomaturalne, 3-letnie licencjaty, 5-letnie magisterskie, podyplomowe 2-semestralne i doktoranckie dość niedookreślone. Autorzy wskazali także na potrzebę funkcjonowania standardów kształcenia i akredytacji, które mają na celu dążenie do zapewnienia wysokiej jakości nauczania i wspierania w tym szkół, oraz punktację ECTS umożliwiającą mobilność studiowania. Standardy europejskie to m.in. programy kształcenia podporządkowane roli społecznej zawodu, pośrednictwa pomiędzy odbiorcą a informacją postawy etyczne zgodne z ideą społeczeństwa demokratycznego, kształcenie metodologiczne, rozwijanie kreatywności; dostosowanie treści nauczania do realiów, różne specjalizacje, wysoka jakość kadry i zaplecza. Zwrócono szczególną uwagę na treści programowe, jak: współczesne technologie, zróżnicowanie usług i użytkowników, niepełnosprawnych, różne nośniki, techniki, marketing informacyjny i biblioteczny, organizowanie i zarządzanie informacja, wysoką wiedzę pozawarsztatowa, umiejętności komunikacyjne, języki obce. Od początku lat dziewięćdziesiątych trwały w Polsce modernizacje programów nauczania; zwrócono uwagę na: wiedzę i umiejętności z zakresu nowoczesnych technologii informacyjnych, wiedzę o nowoczesnych metodach organizacji pracy oraz o funkcjonowaniu bibliotek i innych instytucji informacyjnych w warunkach gospodarki wolnorynkowej i demokratycznych struktur zarządzania państwem.

W 1999 r. rozpoczęła się na łamach „Poradnika Bibliotekarza” kolejna wymiana poglądów - tym razem pomiędzy M. Drzewieckim a Z. Żmigrodzkim. W swoim tekście M. Drzewiecki ${ }^{69}$ stwierdził: „mamy trochę bałaganu" - w latach siedemdziesiątych powstało sporo instytutów kształcących bibliotekoznawców, ale bez kadry, część upadła, część jest, a część nic z tą bibliologią nie robi. Bibliotekoznawstwo to oddzielny kierunek, ale też specjalizacja na jakiejś filologii łączona z dziennikarstwem, komunikacją społeczna, organizacją i zarządzaniem. Jako pryncypia wymienił: 1) pełną świadomość liczby samodzielnych pracowników naukowych w zakresie bibliologii (nie powinny być za wszelką cenę utrzymywane wszystkie ośrodki kształcące); 2) różnorodne, nieporównywalne programy (różne magisteria na tym samym polu

${ }^{69}$ M. Drzewiecki: Szkolnictwo bibliotekarskie w Polsce na rozdrożu. „Poradnik Bibliotekarza" 1999 nr 1, s. 8-10. 
kształcenia, brak drożności), strach przed licencjatami (bo magisterium to prestiż, a licencjat obniża rangę kształcenia) 3) niezbędne warunki uprawianej dyscypliny (nadal na studiach jest problem ze sprzętem, jego wykorzystaniem, dostępem do lektur).

$\mathrm{W}$ polemice $\mathrm{Z}$. Żmigrodzki ${ }^{70}$ nie zgodził się ze stwierdzeniami, pisząc, że przedstawione przez niego mankamenty studiów (brak literatury, kadry, wyposażenia, problemy terminologiczne) dotyczą niemalże chyba wszystkich kierunków, nie tylko bibliotekoznawstwa. Uznał naśladowanie zachodniego systemu studiów licencjackich za bezmyślność, akredytację za niepotrzebną, a wymóg liczby pracowników za nielubiany w środowisku.

W tym samym numerze $\mathrm{M}$. Drzewiecki ${ }^{71}$ napisał, że złe kształcenie geologów nie oznacza złego kształcenia bibliotekoznawców, a wymóg liczby pracowników jest wszędzie krytykowany tam, gdzie ich brakuje. Autor zauważył, że skoro aspirujemy do UE, będziemy musieli dostosować nie tylko szkolnictwo wyższe, akredytacja nie będzie sprawiedliwa, ale da wymierne korzyści. Pisząc o dostosowywaniu prawodawstwa polskiego do europejskiego, poruszył także kwestię podniesienia płac.

Trzy lata później (2002) artykuł dotyczący akredytacji, również autorstwa M. Drzewieckiego, zamieszczono w ZIN-ie ${ }^{72}$. I tak 16 lutego 2001 r. Uniwersytecka Komisja Akredytacyjna uchwałą nr 100 wszczęła postępowania akredytacyjne kierunku bibliotekoznawstwo i informacja naukowa. Dwa miesiące później (20 kwietnia 2001), uchwałą nr 136, powołano grupy ekspertów do określenia standardów. Znaleźli się w nich: M. Kocójowa (UJ) - przewodnicząca, B. Sosińska-Kalata (UW), Anna Sitarska (Uniwersytet w Białymstoku), Wanda Pindlowa (UJ), M. Drzewiecki (UW), Barbara Zybert (UW), Bronisława Woźniczka-Paruzel (Uniwersytet Mikołaja Kopernika), Małgorzata Komza (UWr), Irena Socha (Uniwersytet Śląski), Hanna Tadeusiewicz (UŁ), Barbara Trelińska (Uniwersytet Marii Curie-Skłodowskiej), K. Migoń (UWr). Uchwałą nr 169 z 12 X 2001 r. zatwierdzono standardy, według których w 2002 r. oceniono siedem jednostek. Jako warunki wstępne akredytacji wskazano: minimalną obsadę kadrowa, program nauczania, bazę naukowo-dydaktyczna, ocenę jakości kształcenia; ocenie podlegały: stan kadry naukowo-dydaktycznej, jakość badań realizowanych $\mathrm{w}$ jednostce $\mathrm{z}$ ostatnich trzech lat, wartość realizowanego programu, baza naukowo-dydaktyczna, jakość kształcenia.

70 Z. Żmigrodzki: Cienie i blaski „rozdroża”. „Poradnik Bibliotekarza” 1999 nr 4, s. 8-9.

${ }^{71}$ M. Drzewiecki: Odpowiedź na tekst Z. Żmigrodzkiego "Cienie i blaski »rozdroża«". „Poradnik Bibliotekarza" 1999 nr 4, s. 9-10.

${ }_{72}$ M. Drzewiecki: Akredytacja kierunku Bibliotekoznawstwo i Informacja Naukowo-Techniczna. „Zagadnienia Informacji Naukowej” 2002 nr 2, s. 119-124. 
Krytyczny tekst rozliczeniowy, wskazujący grzechy główne kształcenia bibliotekarzy w polskich szkołach wyższych, autorstwa Stefana Kubowa, opublikowano w numerze 4 ,Bibliotekarza” z roku 2002 ${ }^{73}$. Autor wskazał brak strategicznego myślenia marketingowego, dostosowania do realiów rynku i konkurencji, którego skutkiem stały się: (1) brak systematycznego myślenia nad modelem (modelami) współczesnego bibliotekarza i bibliotekarza przyszłości; (2) brak pełnej drożności systemu kształcenia; (3) brak otwarcia szkół wyższych na praktykę i praktyków jako nauczycieli, odejście od praktyk wakacyjnych; (4) niski poziom nauczania języków obcych; (5) lekceważenie pracy zespołowej; (6) przedmiotowe traktowanie studentów (a student ma być podmiotem), mało możliwości wyboru przedmiotów, seminariów itp., niesłuchanie studentów; (7) niedostatki infrastruktury.

W 2006 r. pojawił się kolejny artykuł M. Drzewieckiego ${ }^{74}$, nawiązujący do omówionych już publikacji, w których poruszono zagadnienia mobilności, akredytacji i standardów kształcenia. Jak zauważył autor, zmiany w bibliotekach powinny pociągnać za sobą zmiany w studiach (o czym pisała już B. Sosińska-Kalata). Przede wszystkim należy zapewnić drożność pionowa czyli spójność merytoryczną i formalno-organizacyjną programów studiów realizowanych na poszczególnych poziomach nauczania; mobilność pozioma, czyli zindywidualizowanie nauczania poprzez dostosowanie oferty do zainteresowań, możliwość studiowania $\mathrm{w}$ różnych ośrodkach (programy wspierające mobilność - Socrates, MOST). Autor wymienił także warunki akredytacji kierunku studiów (analiza specjalizacji naukowej i dorobku badawczego zatrudnionych w uczelni nauczycieli akademickich; udział kadry profesorskiej $\mathrm{w}$ realizacji programu zajęć; odpowiednia proporcja między liczbą studentów a profesorów; właściwe wyposażenie - pracownie, biblioteki, etc.; współpraca z renomowanymi ośrodkami naukowymi kształcącymi w zakresie tego samego kierunku) oraz standardy kształcenia (uwzględnienie w programach nauczania społecznej roli zawodów informacyjnych; nastawienie na kształcenie metodologiczne studenta informacji naukowej; zapewnienie zróżnicowania specjalizacji zawodowych dostosowanych do współczesnego rynku pracy oraz zapewnienie odpowiedniego zaplecza procesu dydaktycznego jako warunku realizacji założonego programu).

${ }^{73}$ S. Kubów: Siedem grzechów głównych ksztatcenia bibliotekarzy w polskich szkołach wyższych. „Bibliotekarz” 2002 nr 4, s. 8-11.

${ }^{74}$ M. Drzewiecki: System kształcenia akademickiego w zakresie bibliotekoznawstwa i informacji naukowej w Polsce na poczatku nowego stulecia. Mobilność - akredytacja - standardy ksztatcenia. „Bibliotekarz” 2006 nr 4, s. 6-9. 
Tekstem kończącym teoretyczne rozważania o standardach kształcenia i akredytacji kierunku informacja naukowa i bibliotekoznawstwo był artykuł Marii Próchnickiej z 2008 r. ${ }^{75}$ Efektem reformy są studia dwustopniowe (I stopień - rozwiązywanie problemów o charakterze zawodowym, II stopień - rozwiązywanie problemów o charakterze strategicznym), określenie sylwetki absolwenta (wiedza, umiejętności, wartości) jako podstawy do tworzenia zakresu kształcenia, ramowe treści kształcenia - treści podstawowe i kierunkowe, efekty kształcenia, drożność systemu, mobilność - ECTS, współpraca ośrodków kształcenia, UKA, obszary współpracy: wymiana studentów i pracowników (Erasmus, MOST, Socrates), kształcenie ustawiczne, współpraca kadry naukowej z praktykami, badania jakości kształcenia, promocja edukacji i kultury informacyjno-komunikacyjnej.

Z treści artykułów wybranych spośród ok. 200 pozycji wyłania się obraz kształcenia bibliotekarzy w Polsce jako ciągle zmieniającego się, ewoluującego, dostosowującego się do nowych warunków, na które zwracają uwagę instytucje międzynarodowe (m.in. IFLA, UNESCO), ośrodki kształcenia (głos zabrali przedstawiciele większości placówek kształcących przyszłych bibliotekarzy na przestrzeni ostatnich 70 lat), aktywni zawodowo bibliotekarze i studenci. Niemalże każdy tekst to kolejne postulaty, propozycje, omówienia potrzeb i zmian. Do najcenniejszych zaliczyć należy dyskusje toczące się na łamach czterech wybranych czasopism, wskazujące nie tylko na zainteresowanie środowiska tą tematyka, lecz także na wieloaspektowość zagadnienia i mnogość spojrzeń na problem - od pierwszego projektu programu studiów w 1945, poprzez wnioski dotyczące niewielkich w nim korekt, zmiany proporcji teorii i praktyki, specjalizacji, ewolucji pojęć i zakresu, po rewolucyjne stwierdzenia, że wyższe studia bibliotekoznawcze są niepotrzebne albo że ośrodków kształcących na tym poziomie jest zbyt dużo; w końcu po podziały studiów na trzystopniowe, ECTS, akredytacje i efekty kształcenia.

Jako podsumowanie analizy obecności zagadnienia akademickiego kształcenia bibliotekarzy na łamach wybranych czasopism branżowych posłużą słowa J. Wojciechowskiego:

Problem kształcenia bibliotekarzy oraz dokumentalistów przewija się przez zawodową prasę, rodzimą i obca, właściwie bez przerw. Dominują teksty sprawozdawcze oraz teksty krytyczne, ale bez wzajemnych powiązań oraz bez ogólnych konkluzji. To chyba niedobrze ${ }^{76}$.

${ }^{75}$ M. Próchnicka: Standardy ksztatcenia $i$ akredytacji kierunku "Informacja naukowa $i$ bibliotekoznawstwo". "Przegląd Biblioteczny” 2008 z. 1, s. 28-38.

${ }^{76}$ J. Wojciechowski: O ksztatceniu bibliotekarzy..., s. 3. 
Ta opinia z roku 1995 nieco straciła na aktualności, ponieważ w programach studiów zaszło wiele zmian - bibliotekoznawstwo i informacja naukowa w 2015 r. jest już inna niż 70 lat temu, w roku 1945, ale też i inne są biblioteki, a, zgodnie z głosem, który wielokrotnie pojawiał się $\mathrm{w}$ przytoczonych tekstach - za ewolucją $\mathrm{w}$ bibliotekach powinny nadążać zmiany w programach kształcenia. Cały czas aktualne pozostaje zdanie z 1983 r., odnotowane w tezach Komisji ds. Kształcenia i Doskonalenia Zawodowego przy Zarządzie Głównym SBP:

Przy różnorodności struktur organizacyjnych bibliotek w kraju i rozległości ich zadań funkcjonalnych oraz przy bogactwie księgozbiorów potrzebne są wysoko kwalifikowane, mądre i twórcze kadry biblioteczne ${ }^{77}$.

\section{Bibliografia}

Aktualne problemy zawodu bibliotekarskiego (Dyskusja w Redakcji). „Bibliotekarz” $1981 \mathrm{nr} 6$, s. 129-143.

Baumgart J.: Międzywydziałowe i podyplomowe studia bibliotekoznawstwa na uniwersytetach w Polsce Ludowej. „Bibliotekarz” 1970 nr 1, s. 1-4.

Brzezińska-Stec H., Żochowska J. (red.): Bibliotekarz uwolniony - deregulacja czy degradacja?: IV Ogólnopolska Konferencja Naukowa Biatystok, 12-14 czerwca 2013 r. Białystok 2013.

Chacewicz K.: Z zagadnień kształcenia i doskonalenia bibliotekarzy szkolnych w Polsce Ludowej. „Bibliotekarz” 1976 nr 4, s. 91-96.

Chmielewski G.: Głos w dyskusji na temat kształcenia bibliotekoznawców. „Przegląd Biblioteczny" 1983 z. 4, s. 411-413.

Chuchro E., Ochmański M., Zając M. (red.): Aktualizacja kształcenia akademickiego bibliotekarzy pracujacych w matych bibliotekach gminnych. Warszawa 2010.

Chuchro E., Ochmański M., Zając M. (red.): Ksztatcenie bibliotekarzy na potrzeby środowisk lokalnych. Programy ksztatcenia uniwersyteckiego. Tom I-II. Warszawa 2011.

Dąbrowska K. (red.): Bibliotekarze, zawód, osobowość, kwalifikacje. Warszawa 1990.

Draczko S.: Kształcenie bibliotekarzy: artykut dyskusyjny. „Bibliotekarz” 1956 nr 6, s. $158-163$.

Drzewiecki M.: Akredytacja kierunku Bibliotekoznawstwo i Informacja Naukowo-Techniczna. „Zagadnienia Informacji Naukowej” 2002 nr 2, s. 119-124.

Drzewiecki M.: Kształcenie i doskonalenie zawodowe bibliotekarzy sieci bibliotek publicznych. Wybrane zagadnienia. Artykut dyskusyjny. „Poradnik Bibliotekarza” $1985 \mathrm{nr}$ 4, s. 135-138.

77 Tezy do powszechnej... 
Problematyka kształcenia akademickiego pracowników bibliotek i informacji naukowej...

Drzewiecki M.: Nie mylić skutków z przyczynami. „Poradnik Bibliotekarza” 1987 nr 5, s. 4-5.

Drzewiecki M.: Odpowiedź na tekst Z. Żmigrodzkiego "Cienie i blaski »rozdroża«". „Poradnik Bibliotekarza” 1999 nr 4, s. 9-10.

Drzewiecki M.: Sprawozdanie z sesji naukowej na temat dydaktyki bibliotekarstwa i informacji naukowej na poziomie wyższym, Warszawa 17-18 II 1976. „Bibliotekarz” 1976 nr 4, s. 100.

Drzewiecki M.: System kształcenia akademickiego w zakresie bibliotekoznawstwa i informacji naukowej w Polsce na początku nowego stulecia. Mobilność - akredytacja - standardy kształcenia. „Bibliotekarz” 2006 nr 4, s. 6-9.

Drzewiecki M.: Szkolnictwo bibliotekarskie w Polsce na rozdrożu. „Poradnik Bibliotekarza" 1999 nr 1, s. 8-10.

Drzewiecki M., Sosińska-Kalata B.: Europejskie standardy kształcenia a restrukturyzacja polskiego systemu edukacji bibliotekarzy i pracowników informacji (program TEMPUS - JEP - 12165-97). "Zagadnienia Informacji Naukowej” 1998 nr 2, s. 87-99.

Edukacja bibliotekarzy 2001: materiały z konferencji międzynarodowej, Warszawa, 6-7 października 1998 r. Warszawa 1998.

Gaca-Dąbrowska Z.: Akademickie ksztatcenie bibliotekarzy dla potrzeb bibliotek publicznych, zwiazkowych i szkolnych. Poznań 1980.

Gałczyńska Cz., Gałczyński J.: Różnorodne jest piękne (i pożyteczne). „Poradnik Bibliotekarza" $1987 \mathrm{nr}$ 10-11, s. 9-11.

Gałczyński J.: O model absolwenta studiów bibliotekoznawstwa i informacji naukowej. "Przegląd Biblioteczny" 1985 z. 1, s. 55-62.

Gawroński A.: Kształcenie bibliotekarzy (głos w dyskusji). „Poradnik Bibliotekarza” 1987 nr 5, s. 10-12.

Gębołyś Z.: Zawód bibliotekarza i kształcenie bibliotekarzy w Polsce. W: Bibliotekarstwo. Red. Z. Żmigrodzki Warszawa 1998, s. 382-402.

Goriszewski W.: Aktualizacja systemu kształcenia bibliotekarzy. „Poradnik Bibliotekarza" 1971 nr 3, s. 67-71.

Gruszka Z.: „Przeglad Biblioteczny”: monografia. Łódź-Warszawa 2012.

Hollender H.: Po pierwsze nie szkodzić. „Poradnik Bibliotekarza” 1987 nr 4, s. 6-9.

Jarowiecki J. (red.): Kształcenie bibliotekarzy szkolnych. Kraków 1993.

Kocójowa M.: Ocena jakości studiów bibliotekoznawstwa i informacji naukowo-technicznej [dalej BIN] w Polsce i akredytacja. W: Społeczeństwo informacyjne: jakość edukacji i pracy bibliotekarzy. Red. nauk. M. Kocójowa. Kraków 2001, s. 36-47.

Kocójowa M.: Przyszłość kształcenia specjalistów informacji naukowej w krajach postkomunistycznych w świetle Generalnego Programu Informacji (zalecenia UNESCO/ IFLA/EUCLID). „Bibliotekarz” 1995 nr 7-8, s. 9-12.

Kocójowa M. (red.): Edukacja z zakresu bibliotekoznawstwa i informacji naukowej na poziomie wyższym w Polsce. Status i przyszłość: Ogólnopolska Konferencja w Krakowie, 26 kwietnia 1995 r. Kraków 1995.

Kocójowa M. (red. nauk.): Światowa strategia edukacji bibliotekarzy i specjalistów informacji naukowej. Kraków 1998.

Kołodziejska J.: Wybrane problemy kształcenia bibliotekarzy. „Bibliotekarz” 1993 nr 7-8, s. 20-24. 
Kubiak S.: Kształcenie bibliotekarzy i pracowników informacji naukowej na poziomie wyższym w Polsce. Zielona Góra 1975.

Kubów S.: Siedem grzechów głównych kształcenia bibliotekarzy w polskich szkołach wyższych. "Bibliotekarz" 2002 nr 4, s. 8-11.

M[uszkowski] J.: Pierwsze polskie przepisy studiów bibliotekarskich na poziomie uniwersyteckim. „Bibliotekarz” 1949 nr 7-8, s. 137-140.

Maj K.: W sprawie kształcenia bibliotekarzy. „Bibliotekarz” 1964 nr 9, s. 259-264.

Michalski L.: Dlaczego się nie zgadzam. „Poradnik Bibliotekarza” 1987 nr 5, s. 6-8.

Michalski L.: Jeszcze raz o tym samym. „Poradnik Bibliotekarza” 1988 nr 1, s. 20-21.

Migoń K.: Wyższe studia bibliotekoznawstwa i informacji naukowej w Polsce w powiazaniu z aktualnymi tendencjami światowymi. "Przegląd Biblioteczny” 1981 z. 3-4, s. $407-411$.

Muszkowski J.: Kształcenie bibliotekarzy. „Bibliotekarz” 1945 nr 2-3, s. 1-6.

Muszkowski J.: Nowe prady w kształceniu bibliotekarzy. „Bibliotekarz” 1949 nr 1-2, s. $1-5$.

Nahotko M.: Bibliotekoznawca to bibliotekarz. „Poradnik Bibliotekarza” 1987 nr 7-8, s. $12-13$.

Nahotko M.: Kształcenie bibliotekarzy na poziomie wyższych - mity i rzeczywistość. „Poradnik Bibliotekarza” 1986 nr 7-8, s. 3-5.

Ogonowska A., Opalińska M.: Nasz projekt programu studiów dla specjalizacji informacja naukowa. „Bibliotekarz” 1994 nr 2, s. 17-25.

Próchnicka M.: Standardy ksztatcenia i akredytacji kierunku "Informacja naukowa i bibliotekoznawstwo". "Przegląd Biblioteczny” 2008 z. 1, s. 28-38.

Puchalski J.: Organizacja kształcenia bibliotekarzy i pracowników informacji naukowej $w$ Polsce w okresie międzywojennym. W: Bibliotekoznawstwo i informacja naukowa. Kształcenie w perspektywie nowego stulecia. Red. E.B. Zybert. Warszawa 1995, s. $12-18$.

Rekomendacje II Forum Stowarzyszenia Bibliotekarzy Polskich nt. "Kształcenie Bibliotekarzy dla Przyszłości”. Jachranka, 22-24 października 1995 r. „Bibliotekarz” 1996 nr 7-8, s. 25-27.

Remerowa K.: Perspektywy rozwoju Katedry Bibliotekoznawstwa Uniwersytetu Warszawskiego. „Bibliotekarz” 1966 nr 5, s. 129-134.

Remerowa K.: Studia bibliotekoznawcze na uniwersytetach polskich. „Przegląd Biblioteczny" 1958 z. 2-3, s. 115-130.

Sekcja IV: Kształcenie i zawód bibliotekarza. Oprac. I. Kuczyńska. „Przegląd Biblioteczny" 1981 z. 3-4, s. 401-420.

Sosińska-Kalata B.: Koncepcja nauczania bibliotekarzy i pracowników informacji naukowej w Polsce po II wojnie światowej. W: Bibliotekoznawstwo i informacja naukowa. Kształcenie w perspektywie nowego stulecia. Red. E.B. Zybert. Warszawa 1995, s. 30-51.

Sosińska-Kalata B.: Nowe możliwości kształcenia bibliotekarzy (1). „Poradnik Bibliotekarza" 1996 nr 9, s. 1-4.

Sosińska-Kalata B.: Nowe możliwości kształcenia bibliotekarzy (2). „Poradnik Bibliotekarza" 1996 nr 10, s. 1-4.

Sosińska-Kalata B.: Perspektywy kształcenia bibliotekarzy - dążenie do standardów światowych. „Bibliotekarz” 1995 nr 7-8, s. 5-9. 
Problematyka kształcenia akademickiego pracowników bibliotek i informacji naukowej...

Sójka J.: System kształcenia bibliotekarzy - propozycje docelowego modelu. „Bibliotekarz" $1984 \mathrm{nr}$ 6-7, s. 172-178.

Tezy do powszechnej dyskusji nad wspótczesnym modelem kształcenia $i$ doskonalenia zawodowego bibliotekarzy. Oprac. J. Ćwiekowa. „Przegląd Biblioteczny” 1983 z. 2-3, s. 301-304.

Walczak M.: Bibliotekoznawca czy bibliotekarz? „Poradnik Bibliotekarza” 1987 nr 1, s. 9-12.

Walczak M.: Koncepcja systemu ksztatcenia, doksztatcania i doskonalenia zawodowego bibliotekarzy w Polsce. „Bibliotekarz” 1986 nr 9, s. 3-14.

Walczak M.: O spójny system kształcenia bibliotekarzy. „Bibliotekarz” 1982 nr 1, s. $17-20$.

Walczak M.: Perspektywa ksztatcenia bibliotekarzy do końca stulecia. „Bibliotekarz” 1988 nr 7-8, s. 3-7.

Walczak M.: Poszukiwanie nowych form kształcenia i doskonalenia zawodowego bibliotekarzy. „Bibliotekarz” 1994 nr 11-12, s. 10-15.

Walczak M.: Problemy kształcenia pracowników dla bibliotek. „Bibliotekarz” 1984 nr 9-10, s. 257-261.

Walczak M.: Wizja kształcenia bibliotekarza nowoczesnego. „Bibliotekarz” 1990 nr 5-6, s. 11-14.

Więckowska H.: Akademickie kształcenie bibliotekarzy (postulaty Raportu o stanie bibliotek i próba ich realizacji). „Przegląd Biblioteczny” 1975 z. 3, s. 219-232.

Więckowska H.: Akademickie kształcenie bibliotekarzy: zarys historyczny. Warszawa 1979.

Więckowska H.: Nowe programy studiów bibliotekoznawstwa i informacji naukowej na tle światowych tendencji programowej. "Zagadnienia Informacji Naukowej” 1976 nr 1, s. 135-149.

Więckowska H.: System kształcenia bibliotekarzy na uniwersytetach polskich. „Przegląd Biblioteczny" 1971 z. 1-4, s. 230-241.

Więckowska H.: Uniwersyteckie kształcenie bibliotekarzy. Problemy dyskusyjne. „Przegląd Biblioteczny" 1972 z. 1, s. 7-22.

Wojakowski J.: Organizacja kształcenia bibliotekarzy i pracowników informacji naukowej w Polsce po zakończeniu drugiej wojny światowej. W: Kształcenie w perspektywie nowego stulecia. Red. E.B. Zybert. Warszawa 1995, s. 19-29.

Wojciechowski J.: O kształceniu bibliotekarzy. „Bibliotekarz” 1995 nr 10, s. 3-5.

Wojciechowski J.: Specjalność - organizacja działalności bibliotecznej. „Bibliotekarz” 1966 nr 12, s. 375-376.

Wyczańska K.: Nowoczesna dydaktyka na użytek studiów wyższych bibliotekoznawstwa i informacji naukowej. Seminarium 17-18 lutego 1976 r. "Zagadnienia Informacji Naukowej" 1976 nr 1, s. 185-188.

Żmigrodzki Z.: Cienie i blaski „rozdroża”. „Poradnik Bibliotekarza” 1999 nr 4, s. 8-9. Żmigrodzki Z.: Daleko od obiektywizmu. „Poradnik Bibliotekarza” 1987 nr 5, s. 5-6. 


\section{The issue of academic education a library staff and an employees of a scientific information on the specialist periodicals pages (1945-2015)}

The history of academic education of librarians in Poland dating back to the early nineteenth century, and his precursors were among Paweł Jarkowski, Jerzy Samuel Bandtkie, Joachim Lelewel and Aleksander Bohatkiewicz. For more than two centuries changed not only the subject of courses, but also forms of education itself and his organization: from lectures, through courses, to the first independent organization - the Department of Library Science established in 1945 at the University of Lodz. The text presents discussions about academic education librarians and experts of scientific information present on the pages of the trade press, for example of four titles: "The Librarian", "The Library Review", "The Guide of Librarian" and "Information Studies" (analysis of 1945 after half of 2015). With articles selected from ca. 200 emerges a picture of education librarians in Poland as a constantly changing, evolving and adapting to new conditions.

Keywords: education, librarian, librarianship, employee of scientific information, information science, discussion, issues 